\title{
Sociolinguistics Analysis on Language Style Form at the Movie Script of Papillon
}

\author{
Dameria Purba, Febi Sulistia, Vebriati Lelyana Br. Manurung, Herman * \\ English Education Department, Universitas HKBP Nommensen, Medan, Indonesia \\ *Correspondence: herman@uhn.ac.id
}

\begin{abstract}
This research discusses language style at the movie script of Papillon. This research aims to classify the type of language style and the functions of the speakers' utterances in using language style at the movie script of Papillon. The data source of this research was YouTube "Papillon" which was aired on September, $2^{\text {th }}$ 2018. This study utilized theories of Martin Joos' types of language styles and Roman Jakobson's function. Data from the Papillon Movie Script. Researchers have implemented qualitative research designs to answer the research question. The researchers used documentation as a tool for research. The researchers found 30 language-style data sets as a result of their investigation. The scientists discovered many linguistic styles. The styles are as follows: 1 data point or $3 \%, 6$ data points or $20 \%$, were discovered in frozen style; 11 data points or $37 \%$, casual style 6 to 20, and intimate style 6 to 20 were found in consultancies. The following five roles were revealed in the language style: expressive, guiding, referential, metalinguistic and phasic. There were 6 data or 20 percent of expressive function; the directive works 3 or 10 percent, the reference function found 8 or $27 \%$, the metalinguistic function discovered 7 or $23 \%$ and the phatic function discovered 6 data or $20 \%$. No poetic function is available in the film.
\end{abstract}

Keywords: Sociolinguistic, Language Style, Movie Script

How to cite this paper: Purba, D. Sulistia, F., Manurung, V. L. B., \& Herman. (2021). Sociolinguistics Analysis on Language Style Form at the Movie Script of Papillon. Universal Journal of Social Sciences and Humanities, 1(1), 37-45. Retrieved from https://www.scipublications.com/journal/index.php/ujssh/article/view/110

Received: July 23, 2021 Accepted: August 26, 2021 Published: August 27, 2021

Copyright: (c) 2021 by the authors. Submitted for possible open access publication under the terms and conditions of the Creative Commons Attribution (CC BY) license (http://creativecommons.org/licenses /by/4.0/).

\section{Introduction}

The introduction should briefly place the study in a broad context and highlight why Language is one of the tools used in your everyday lives by everybody. Language is a tool for communications that plays an important part in communication [9]. To communicate with others, people use language. They use different languages when talking to others in different situations. People can interact and communicate with others through language, and people can also share information in dialog with others. In the dialogue, people can convey their own information, so that they can interact and communicate.

Many languages, including Spanish, Japanese, Mandarin and more, exist worldwide. English is the only language spoken by people around the world that has become an international language. English is a global language that is used as a means of communication between nations that speak different languages. According to Mappiasse and Johari, English is one of the most spoken languages in the world today [13]. English has become the most important language in the world because nearly everyone from all over the world uses it to communicate and interact with others. As an international language, English is very important. It has many connections with all aspects of human life. Since English is regarded as an international language, students from all over the world are learning English.

Speaking of language, there is a study of language called linguistic. Linguistic is the scientific study of language. In communication, the relationship between society and language is inseparable. One of the linguistic that studies the relationship between society 
and language is called sociolinguistic. Georgieva states that sociolinguistics explores language in relation to society [5]. Hence, sociolinguistic is the study of human beings and society. Because of sociolinguistic, it can help people learn more about the language used for social communication.

There are many kinds of languages used in society. The language of society is usually different in every place because every society has a different culture. Sociolinguistic can be defined as the detailed study of social language. Every society has a relationship between language and society. It becomes a language that becomes social identity. Wardhaugh said there are three possibilities for language to become a social identity. One is that social design may impact or decide language structure or potentially conduct. The second possible relationship is directly opposed to the original one: linguistic structure and behavior may influence or determine social construction. Thirdly, the impact is twoway: language and society can affect each other [28]. Therefore, language and society are interrelated, and society or language can be isolated, because language can be the personality of society.

As quoted in Wardhaugh, Fishman claimed that the study of society-connected language is called sociolinguistic, which consists of two words: society is social and related, and language is linguistic [28].

People use a variety of language styles in communication. For example, the language used in meetings is formal, not the language used in daily communication with friends. In language, certain words also play a very active role in certain sentences. As a result, Meyerhoff, as cited in Sipahutar claims that language style can also depict a person's character, attitude, or state $[15,21]$. Human language style can be influenced by a person's state. When the president delivers a speech in front of the residents, for example, formal language will be used. This is due to the fact that the setting is formal and has specific purposes for conveying such data. When a father converses with a mother, the circumstances are completely unique. In general, father used intimate language with mother to the extent that it is justifiable. When two people have a close relationship, they will use personal language. For example, between life partners, they usually use "honey," "baby," or another call name that is unique to their current situation, as it were.

The job of language in communication is to communicate information or ideas from the speaker to the listener. It has a wide range of styles and each style plays a significant part in the achievement of social interaction and comprehension in language of the significance of social communication. Its style also helps people who speak the language to understand. Joos asserts that language has five different styles: frozen, formal, consultative, casual, and intimate $[8,10]$

Language is an interact of communications through language often reflective of the spirit and the character of the author, or language user [1, 19]. Their discussion uses a range of language patterns in this film. Language studies is often a social context study. Language examines. As we learn multiple linguistic types, it is difficult to detach from society. The talk or dialog is a case of a style of the language formed by the characters of the film and the words in which the dialog is shaped.

The language style is categorised into five varieties, depending on the formality level $[2,27]$. These style are intimate, frozen, formal, advisory and informal. The way people talk depends not only of regional and social dialect but also of circumstance [24]. Style refers to the distinct manner people speak in a particular setting.

One way to learn about language style is to watch a movie. A film, usually referred to as a movie, is a kind of visual communication that tells stories for pleasure with moving images and sounds [14]. The actors in movies introduce the conversation by presenting the dialogues written from the movie script. For these reasons, watching a movie is a fun way to learn about different language styles. Every human being employs a language style in their everyday speech and communication. A movie to present the expressions that are 
generally used in human life since film is really a portrayal of genuine discussion in characteristic culture. Particularly film is one of the medium where to establish kinds of language style. The creation of film additionally has a social measurement for a few reasons. Film producers are citizen. Each film has one of a kind style. It can show from the exchange of the character in the film. Each character has the distinctive of the style when they talk, particularly of the opponent or hero.

Researchers are interested in analyzing language styles, because of some problems, sometimes there are still communication misunderstandings in daily life. How people use their own styles to communicate, and when to use various language styles. It is typical of this language to speak the languages of official or casual, ordinary or secret, which listens to us, be it friends, parents or aliens. The researchers seek to ensure that the five language types are well understood by readers so they may use them in their daily lives. The language style of Sapriyani et al is the preferred language approach [19]. It refers to the way in which multiple terms are utilized to convey the same information and to the variances in the language used in different contexts and requirements. On the other side, the linguistic style is the way in which we express ourselves, formally or informally. In this situation, the researchers would like to determine which language styles are frequent throughout the world in various circumstances.

\section{[1] For example:}

Nannete: Papi, I love you

The statement above is categorized as intimate style because occurred in relax situation. Joos theory explained that the word generally signal intimacy such as "Dear, Darling, Honey, and the other names. It excludes of public information and shows the intimate relation or closeness.

\section{[2] Example of Casual style}

- Papillon: Hey Julot. Take the corner

- Julot: Looks like Dega's making friends already

- Papillon: Julot, make sure no one takes this hammock

These chats are described as informal since they happened in a relatively relaxed environment between friends, namely the name. Joos's theories suggest that informal styles are employed to converse with our friends or sometimes family members in our relaxed, typical circumstances.

A few scientists have researched linguistic style. Lailah, for example, undertook a study entitled Language Analysis Used in the movie "Two Fasters and Two Furious." The study tries to recognize the many sorts of styles of language, when utilized in films, using the theory of Martin Joos. The film only used four language styles: frozen, consultive, informal and intimate. The film was found by Lailah. Lailah's study differs from Lailah's. The research purpose. In this study, however, researchers seek to determine the role of the language in a film Lailah discussed the numerous language models [11].

\section{Methods}

\subsection{Design of the Research}

Two types of research are available: qualitative and quantitative. In this study the scientists used a qualitative approach to the library research design. In order to analyze the subject, the researchers used the descriptive qualitative design. This research is most appropriate for analysis and research, because a detailed description of the linguistic style is expected to result.

According to Silalahi, qualitative research is when information is gathered through words or pictures rather than numbers [20,22]. Furthermore, qualitative methods are used to describe data [18]. One of the characteristics of the qualitative method is the ability to 
comprehend the process we must deal with based on the settings; the location of the research [7].

The data from qualitative research is not calculated, but rather displayed through a description of the outcome. Researchers gathered and analyzed data in the form of words, so the research design was qualitative in nature.

Seven types of qualitative research are available. Exhibits of research methods can be found in case studies, content or document analysis, ethnographic studies, grounded theory studies, historical studies, narrative research and phenomenological research [4]. Researchers have used content or document analysis. The content or document analysis is a method for research used to identify certain characteristics of written or visual material [4]. A wide range of other documents can be analyzed including textbooks, newspapers, webpages, speeches, TV programs, publicity, music compositions and other documents. Films are the subject of this study by the researchers. You can analyze the script for the film.

\subsection{Data Source of the Research}

The research is aimed at obtaining data. The data are information or data used to discuss or to decide on a research question response, $[3,26]$. Papillon film script is the source of the data. The examined number of data is 30 . The film is 133 minutes in length. This movie was published at 9 September 2017. The researchers chose this movie as the object because the researchers found that the conversation in entire scene almost contains style, and the style of the characters when they speak is different.

\subsection{Instruments of the Research}

A research instrument is a device that collects and analyzes data from subjects related to the research topic. It is critical to select the best instrument for the type of research, and qualitative research is the type of research. Qualitative research methods are, according to Sugiyono, methodologies used in research to study the conditions of natural objects with researchers acting as the major data collecting participant [17, 23]. Furthermore, Ary et al state that the most commonly used data collection methods in qualitative research are interviews, observations, questionnaires, and documentation [4]. Interview is an activity that involves both the interviewer and the interviewee; the interviewer will ask the question, and the interviewee will respond. Observation is an activity that involves paying close attention to something or someone in order to learn more about them. A questionnaire is a method of collecting data that consists of asking questions or making statements. Documentation is an extremely useful source of information.

The researchers used You-Tube and a documentation technique to collect data for this study. You-Tube was used to search for the movie, and documentation was used to collect the script of Papillon, which was obtained from the Internet.

\subsection{Technique of Data Collection}

The data for this study was collected through the use of literature techniques. Sugiyono stated that documents and pictures can be written by people who can be used to obtain information [23,25]. Researchers classified language styles according to Joos in Ukhtin discuss language styles [27]. In short, when analyzing data, you should also follow the steps below:

1. Searching the movie and the script in internet

2. Downloading the movie from cinemakeren $21 . c 0 m$

3. Documenting the script of the movie

4. Watching the film "Papillon" over and over again while reading the transcript

\subsection{Technique of Data Analysis}

Analyzing data, according to Nainggolan et al, is a process that systematically finds and organizes data derived from interviews, observations, and documentation [16, 6]. 
When analyzing data from this study, the researchers choose to apply various methodologies for accurate data analyzes. The researchers' first step is to compile a list of the data containing the language patterns used in the Papillon movie script. The researchers then classified them based on Martin Joos' theory's language style. Furthermore, the researchers applied Jakobson's theory to analyze functions in language style.

When analyzing the data, the following steps are also performed:

1. Watching the movie and found the language style.

2. Underlining the language style based on the theory of Martin Joos

3. The films collect the data by getting the discussion screenplay that takes place in the film.

4. Identifying each transcript of the dialogue in the movie in order to find the language style that used in the utterances.

5. Classifying the language styles. The data are selected and classified into the five language styles based on Martin Joos's theory.

6. Analyzing and discussing the significances of the data.

7. Drawing some conclusions and suggestions. In the final step, the researchers drew some conclusion about the data analysis and providing some suggestion.

\section{Results}

\subsection{Research Findings}

Like in the Introduction, the aim of this study is to find out the types of language in the Papillon movie script and the functions in language style of the speaker in the Papillon movie screenplay. The researchers present a concise picture of the employment of the language style and function in the film screenplay

\subsubsection{Types of Language Style}

The researchers found 30 language-style data based on data analysis. The following table provides the linguistic statistics presenting each other's total number and frequency

Table 1. Types of Language Style at the Movie Script of Papillon

\begin{tabular}{|c|c|c|c|}
\hline No. & Types of Language Style & Number of Cases & $\begin{array}{c}\text { Percentages of } \\
\text { Types }\end{array}$ \\
\hline 1 & Frozen Style & 1 & $3 \%$ \\
\hline 2 & Formal Style & 6 & $20 \%$ \\
\hline 3 & Consultative Style & 11 & $37 \%$ \\
\hline 4 & Casual Style & 6 & $20 \%$ \\
\hline 5 & Intimate Style & 6 & $20 \%$ \\
\hline & Total & 30 & $100 \%$ \\
\hline
\end{tabular}

The researchers found five kinds of language style based on the table above. They are intimate, frozen, formal and consultative style. They are casual. All types show the frequency of each other by diagram. 


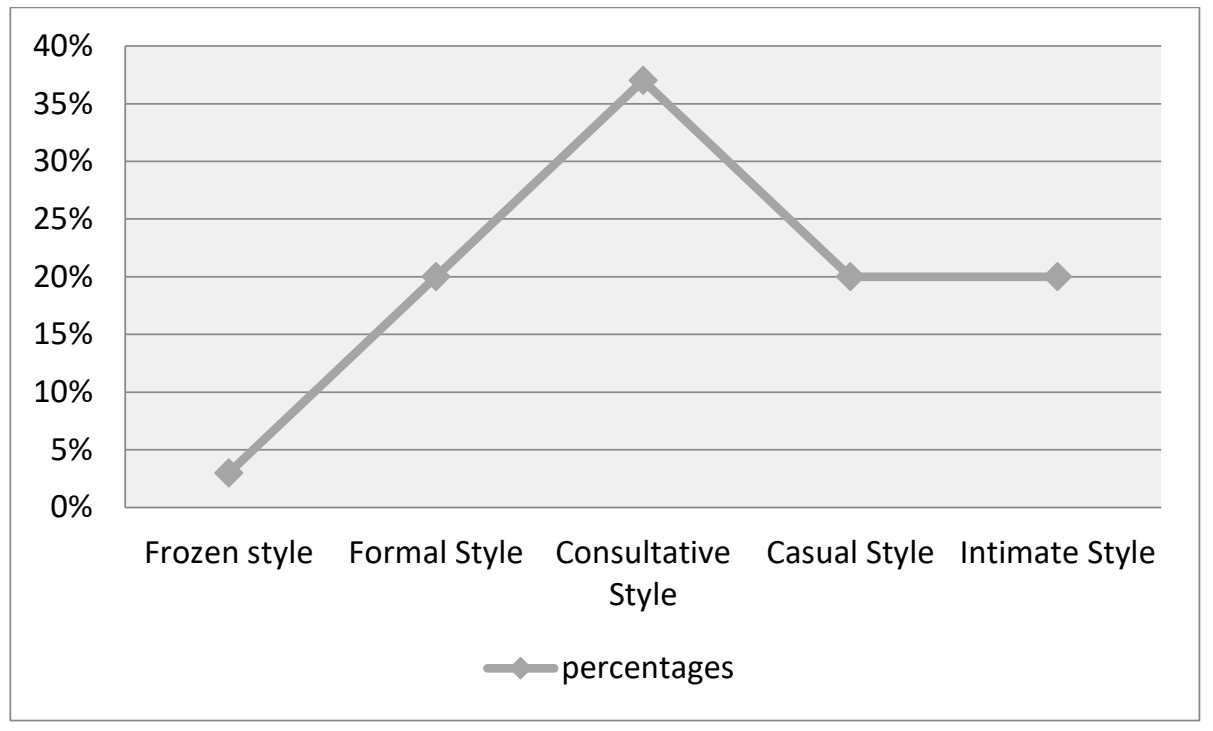

Figure 1. Types of Language Style at the Movie Script of Papillon

According to the chart above, consultative style is the most common type of language style used by the character in the Papillon movie script. The researchers discovered five different types of language styles in the Papillon script. There is one data point for frozen style, six data points for formal style, eleven data points for consultative style, six data points for casual style, and six data points for intimate style. The researchers discovered formal style 6 data (20\%), consultative style 11 data (37\%), casual style 6 data (20\%), intimate style 6 data (20\%), and 1 data for frozen style (3 percent)

\subsubsection{The functions of the speakers' utterances in using language style}

Language has in general some features used by human needs as a means of expressing ourselves, communicating, organizing, adapting to social integration and social control in the environment [12].

The researchers are analyzing the functions of language styles in this study with Herbert's explanation because they are clearer than others. After analyzing the data, he researchers discovered five functions of language style based on the table above. These are the expressive function, the directive function, the referential function, the metalinguistic functions, and the phatic function. To know the frequency of each other, all functions are displayed in chart form.

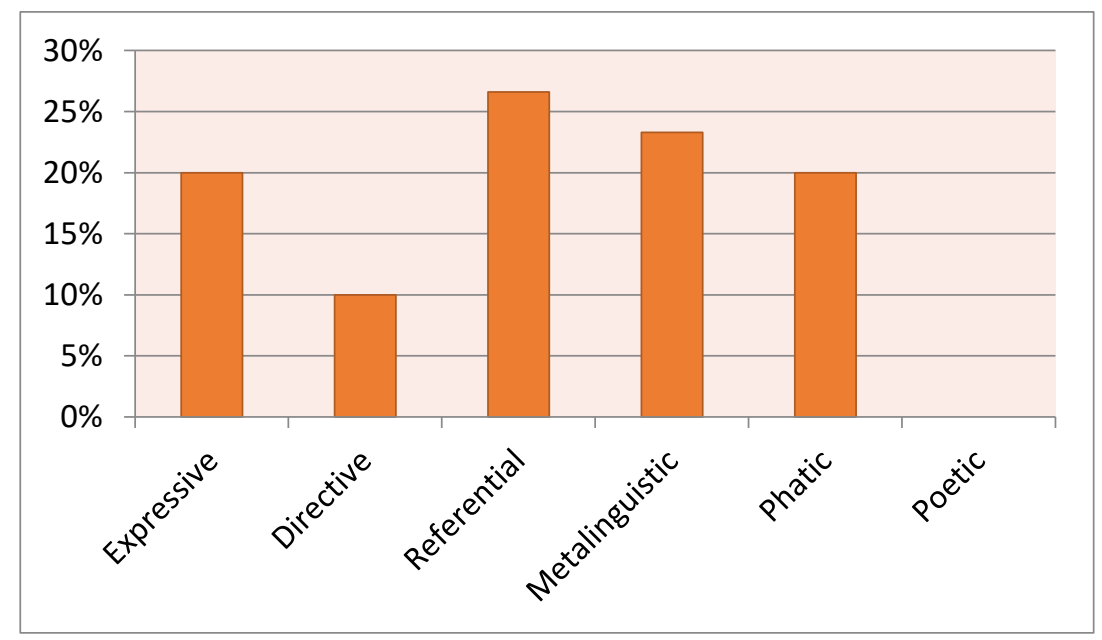

Figure 2. The functions of the speakers' utterances in using language style at the movie script of Papillon 
The function of speakers' utterances can be divided in to six categories; they are expressive function, directive function, referential function, metalinguistic functions, and phatic function and poetic function. All the utterances produced by the speaker delivered well. Based on the data, the researchers found that are 5 functions that happened at the movie they are 6 data of expressive function, 3 data of directive function, 8 data of referential function, 7 data of metalinguistic function, and 6 phatic function. There is no poetic function at the movie. The researchers also found that there are $20 \%$ expressive, $10 \%$ directive, $27 \%$ referential, $23 \%$ metalinguistic and $20 \%$ phatic. There is no poetic function at the movie.

\section{Discussion}

In this circumstance, we must utilize some language to communicate correctly. It refers to the way different terms and linguistic variations are utilized in different contexts or needs to convey the same information. In other possibilities, Ducrot and Todorov, as referred to in the Lailiyah are also available in the linguistic style [12]. The language style of the speaker depends on the speaker's talk and the communication between the speaker and the listener. The separated language style into five styles is frozen, formal, consultative, casual and intime, based on the idea of Martin Joss.

The researchers discussed the whole data after evaluating the data and answered questions about research/research. The researchers selected 30 data containing different kinds of language in the film. The linguistic types contain 1-data (3\%), 6-data (20\%) in the official way, 11-data in consultative style (37\%), 6-data in informal style $(20 \%)$ and sixdata intimate (20 percent).

Based on the results of this investigation, the researchers identified some distinctions between this study and earlier studies. Unlike in past research, Amanda Brown carried out a study entitled The Language still Used by Lailiyah, a student at Sunan Ampel Surabaye University, in Lailiyah's Legally Blonde Movie in 2018. The purpose of the research is to characterize the language styles employed by the film Legally Blonde's principal character, to detect the social elements which influence the main person through dialogue, and to disclose the linguistic function of the principal person. The qualitative descriptive method was used in this investigation. The information comes from the character's crucial words in the Legally Blonde movie. Martin Joos writes the theory adopted by Lailiyah. This study is comparable to Lailiyah's research. Both employ the same idea as Martin Joos, and the object used is the same as the movie, with Lailiyah using Legalement Blonde Movie as the sole difference. The researchers used the study "Papillon Movie."

The functions of linguistic styles are also essential in this study. The speaker speaks all the functions of linguistic styles. Because each function plays a significant effect in language styles. It's correct to do that. The talk uses the expressive function to communicate your feelings. This directive function is used to persuade everyone to do something. Then the reference function of the context factor. It is knowledge. It is knowledge. It is knowledge. It is knowledge. It might be a condition, an object or a mental state. The metalinguistic function should also be discussed, clarified and renegotiated. The esthetic features of language can play a poetic role. Like greetings, the last Phatic function is to show togetherness.

\section{Conclusions}

Based on the findings and discussions, the researchers concluded as follows:

1. The purpose of this study is to evaluate different styles of language present in the film script of Papillon. Researchers used Joos' hypothesis in five categories to define distinct language styles. They are intimate, formal, advisory, informal and frozen. The following language kinds have been discovered by researchers: Style 6 data 
(20\%); data 11 data style consultations (37\%), style 6 data casual (20\%), data 6 style intimate (20\%) and 1 frozen style style data (3 percent).

2. The functions of the language speech of the speakers in the film scription Papillon in this examination. 2. In categorizing forms of function, researchers employed Jakobson's hypothesis. The researchers determined the role of the speakers in employing language style at the Papillon movie screenplay, based on the findings and comments above. In classified forms of language theory, researchers applied Jakobson's theory in 6 kinds. They consist of expressive 6 data, 3 data, metalinguistic seven data, 8 data, Phatic 6 data. They are expressive function. No poetic function is given in the film.

To sum up, the analysis in this research shows that the movie use the right types and function of language style when they speak. The participants knew when they speak and how to speak with other in such formal style. The participant follows the rule of conversation and they know the time they should speak.

\section{Patents}

This section is not mandatory but may be added if there are patents resulting from the work reported in this manuscript.

Funding: This research received no external funding.

\section{References}

[1] Anekawati, F., Nababan, M. R., \& Santosa, R. (2020). Translation Technique Analysis of Language Style of Nic's Character in Beautiful Boy by David Sheff. Available at SSRN 3528096.

[2] Apriyani, I. and Suwarsih, A. (2019). Using Language Casual Style in Teenagers 17 Years old on Instagram Comment. Siliwangi: Professional Journal of English Education.

[3] Arikunto, Suharsimi. (2010). Prosedur Penelitian Suatu Pendekatan Praktik. Jakarta: Rineka Cipta

[4] Ary, D., Jacobs. L.C., Sorensen, C. (2010). Introduction to Research in Education (8thEd.). California: Wadsworth

[5] Georgieva, M. (2014). Introducing Sociolinguistics. St. Kliment Ohridski: University of Sofia.

[6] Herman, Sinurat, B., and Sitio, I. T. (2019). Ethnography of Communication Analysis in the Short Story of Romeo and Juliet. International Technology and Science Publications (ITS) Education Journal Volume 2, 2019. ISSN: 2617-4588, DOI: 10.31058/j.edu.2019.23002, page 41-50. Retrieved from http://www.itspoa.com/itsadmin/Ll/LL.DE.asp?action=Paper_Information\&id=1785\&at=Ethnography \%20of\%20Communication \%20Analysis\%20in \%20the\%20Short \%20Story \%20of $\% 20$ Romeo\%20and\%20Juliet\&jn=Education\%20Journal

[7] Herman, Murni, S. M., Sibarani, B. and Saragih, A. (2019). Structures of Representational Metafunctions of the "Cheng Beng" Ceremony in Pematangsiantar: A Multimodal Analysis. International Journal of Innovation, Creativity and Change., Volume 8, Issue 4, 2019. Retrieved from https://www.ijicc.net/images/vol8iss4/8403_Herman_2019_E_R.pdf

[8] Hornberger H. Nancy. (2010). Sociolinguistics and Language Education. USA: Short Run Press.Ltd

[9] Hutajulu, F. L. S. and Herman. (2019). Analysis of Illocutionary Act in the Movie "You Are My Home" English Subtitle". Journal of English Educational Study Volume 2 Issue 1 May 2019 Page 29-36. E-ISSN: 2655-0776. Retrieved from http://jurnal.stkippersada.ac.id/jurnal/index.php/JEES/article/view/371

[10] Joos, M. (1967). Five Clocks. London. New York: Harcourt Brace and World, Inc.

[11] Lailah, N. (2015). An analysis of Language Style Used in "Two Fast and Two Furious" Movie (Doctoral dissertation, UIN Sunan Ampel).

[12] Lailiyah, D. R. (2018). Language style used by main character in legally blonde movie by Amanda Brown (Doctoral dissertation, UIN Sunan Ampel Surabaya).

[13] Mappiasse, S. and Johari, A, (2014). Evaluation of English as a foreign language and its curriculum in Indonesia: A review. English language teaching. Faculty of education, 7(10), 113-122

[14] Maraden, S. (2016). Language Style Found in Indonesian Movies. The Episteme Journal of Linguistics and Literature, 3(1), 3-25.

[15] Meyerhoff, M. (2006). Introducing Sociolinguistics. London: Routledge Francis

[16] Nainggolan, F., Siahaan, D. A., Sinurat, B., and Herman. (2021). An Analysis of Figurative Language on Joe Biden's Victory Speech. International Journal on Integrated Education, Vol. 4 No. 3 (2021), PP. 364-375, DOI: https://doi.org/10.31149/ijie.v4i3.1514. Retrieved from: https://journals.researchparks.org/index.php/IJIE/article/view/1514

[17] Nurjannah, N. (2014). The Analysis Of Language Style Used By The Spekers In'The Tonight Show With Jay Leno Talk Show Season 21 Episode 145 (Doctoral dissertation, Universitas Islam Negeri Alauddin Makassar).

[18] Purba, R. and Herman. (2020). Multimodal Analysis on Ertiga Car Advertisement. Wiralodra English Journal (WEJ), Vol 4 No 1 Maret 2020, PP. 21-32. Retrieved from http://wej.unwir.ac.id/index.php/wej/article/view/77 
[19] Sapriani, D., Syarif, H., \& Ardi, H. (2013). Analysis of Language Style found in Novel the Last Tycoon written by F. Scoot Fitzgerald. English Language and Literature, 2(1).

[20] Silalahi. (2015). The Learners on Figurative Language at FKIP UHN Pematangsiantar. http://repository.uhn.ac.id/handle123456789/3690_

[21] Sipahutar, I. Y. (2018). Language Styles in "Love Rosie" Movie: a Sociolinguistic Analysis.

[22] Situmorang, R. K. and Herman. (2021). An Analysis of Slang Language Styles Used in Charlie's Angels Movie. Journal of English Educational Study (JEES), Vol. 4, No. 1, PP. 21-29. DOI: https://doi.org/10.31932/jees.v4i1.820. Retrieved from: http://jurnal.stkippersada.ac.id/jurnal/index.php/JEES/article/view/820

[23] Sugiyono. (2008). Metode Penelitian Kuantitatif, Kualitatif, dan RED. Bandung: Penerbit Alfabeta

[24] Tarigan, A. P. (2016). An Analysis of Stylistic On Djaga Depari Songs Lyrics: a Sociolinguistics Study. Retrieved from: http://repository.uhn.ac.id/handle/123456789/670

[25] Thao, N. V. \& Herman. (2021). An Analysis of Idiomatic Expressions Found in Ed Sheeran's Selected Lyrics Songs. CENTRAL ASIAN JOURNAL OF LITERATURE, PHILOSOPHY AND CULTURE, 2(1), 12-18. Retrieved from http://cajlpc.centralasianstudies.org/index.php/CAJLPC/article/view/54

[26] Thao, N.V., Sinaga, M. R., and Herman. (2021). Semantic Analysis of Contextual Meaning in Dialogue of "The Ugly Duckling" Short Story. Walailak Journal of Social Science, Vol. 14 No. 2 (2021): March - April, E-ISSN: 2697-6390. Retrieved from: https://so06.tci-thaijo.org/index.php/wjss/article/view/239940

[27] Ukthin, A. (2021). The Language Style of Millenial Generation in Their Twitter Statuses. Medan: Universitas Sumatera Utara

[28] Wardhaugh, R. (2010). An Introduction to Sociolinguistics, Sixth Edition. Oxford: Blackwell Publishing 